\title{
12. ENVIRONMENTAL TRENDS AMONG NEOGENE BENTHIC FORAMINIFERS AT DEEP SEA DRILLING PROJECT SITE 548, IRISH CONTINENTAL MARGIN ${ }^{1}$
}

\author{
C. Wylie Poag and Doris Low, U.S. Geological Survey, Woods Hole ${ }^{2}$
}

\begin{abstract}
An analysis of diversity and abundance trends among all benthic foraminiferal genera and species, and particularly among species of Bolivina, was carried out for 59 samples of Neogene sediment from DSDP-IPOD Site 548, Goban Spur. By correlating these census data with lithological, geophysical, geochemical, and other faunal and floral measurements in the same stratigraphic interval, a record of irregularly fluctuating cycles was compiled. We interpret them as indicators of relative sea level. High sea levels are characterized by pelagic sedimentation and by high generic and total species diversities. During low sea level, diversity values were lower, and the accumulation of terrigenous detritus was more prevalent at the site. A sequence recording five highstands and five lowstands is interrupted by four unconformities in a scenario remarkably similar to that postulated in the work of P. R. Vail and his colleagues.

Bolivina species diversity also varied cyclically. We interpret diversity of Bolivina species as a measure of relative oxygen and nutrient content at the water/sediment interface; high diversity indicates the presence of an oxygen-minimum layer, accompanied by nutrient enrichment. Our data show that this property generally varied directly with sea level, but sometimes varied independently.
\end{abstract}

\section{INTRODUCTION}

Site 548 is on the upper continental slope of Goban Spur, a physiographic nose that extends from the Irish continental margin southwestward toward Porcupine Abyssal Plain (Figs. 1 and 2). The site is $112 \mathrm{~km}$ from the shelf edge and $270 \mathrm{~km}$ from the southeastern coast of Ireland. The broad, shallow Western Approaches shelf separates it from the southern coast of Cornwall, 625 $\mathrm{km}$ distant. Seismic and stratigraphic studies of this passive margin (Roberts and Montadert, 1979; Roberts et al., 1981; Masson et al., this vol.) indicate that it has been tectonically stable during most of the Cenozoic, that faulting has been minor, and that subsidence has proceeded at a slow pace $(\sim 12 \mathrm{~m} / \mathrm{m}$.y.). Thus, this shallow site serves as a good station for monitoring the effects of eustatic sea-level changes, shifts in the sites and rates of terrigenous deposition, and changes in shallow water-mass composition and distribution.

The purpose of this chapter is to examine broad trends in the composition of Neogene benthic foraminiferal assemblages in this passive continental slope setting and to evaluate the use of these assemblages as indicators of the depositional environment. This is the first time that a continuously cored section of Neogene sedimentary rocks has been recovered from the upper continental slope (1249 m water depth) in the North Atlantic. Therefore, this study is the initial examination of interactions between epibathyal foraminiferal assemblages and environmental factors operative during the Miocene and Pliocene. The closest site previously studied (DSDP Site

\footnotetext{
${ }^{1}$ Graciansky, P. C. de, Poag, C. W., et al., Init. Repts. DSDP, 80: Washington (U.S Govt, Printing Office)

2 Address: U.S. Geological Survey, Woods Hole, MA.
}

400 ) is $270 \mathrm{~km}$ southeast of Site 548 , on the Armorican Margin in $4399 \mathrm{~m}$ of water (Schnitker, 1979).

\section{METHODS}

The sampling plan was to take at least one 2- to $3-\mathrm{cm}^{3}$ sample from each core in the Neogene interval at Site 548 (Hole 548, Cores 15-35; Hole 548A, Cores 2-15; Figs. 3-5); in some cores, however, more than one sample was taken. A few samples were taken from Pleistocene and Oligocene strata to document faunal transitions at the upper and lower boundaries of the Neogene section. All together, 59 samples were analyzed. The interval between samples represents approximately 18,000 yrs. in the Pliocene and uppermost Miocene (samples 27-56), $4900 \mathrm{yrs}$. in the remainder of the upper Miocene (samples 15-26), and $1.3 \mathrm{~m} . \mathrm{y}$. in the middle Miocene to lower Oligocene (samples 1-14; Fig. 5). Each sample was soaked in Calgon, a commercial water softener, and rinsed through a 74- $\mu \mathrm{m}$ screen. Each sample was split, and one quarter was examined thoroughly to identify all the species present. The relative abundance of each species was estimated from examination of the fraction larger than $74 \mu \mathrm{m}$.

Initial analysis treated these census data at the generic level, to minimize evolutionary effects that could be expected to change assemblages at the species level. It has been amply demonstrated (Walton, 1964; Erez and Gill, 1977; Poag, 1981) that faunal responses to environmental changes in modern oceans are distinct at the generic level, and that presence/absence and relative abundance data are sufficient to detect these responses.

Further analysis was carried out with Bolivina at the species level, because Bolivina (sensu lato) is the most persistently abundant and diverse group of benthic foraminifers in all our samples (Fig. 3). It was expected that a study of the distribution of these species would amplify the interpretation based upon generic analysis. The stratigraphic range of each bolivinid was recorded, and the relative abundance of each species relative to other bolivinids was estimated by the methods used for the generic census.

Generic categories used in this study are conservative. In some cases two or more morphologically similar forms are combined, although they have been frequently separated as different genera by other authors. The chief examples of this are the combining of Brizalina with Bolivina, Cibicidoides with Cibicides, and Islandiella and Globocassidulina with Cassidulina. The individual members of any one of these three groups appear to have nearly identical environmental requirements, and morphological differences used for generic "split- 


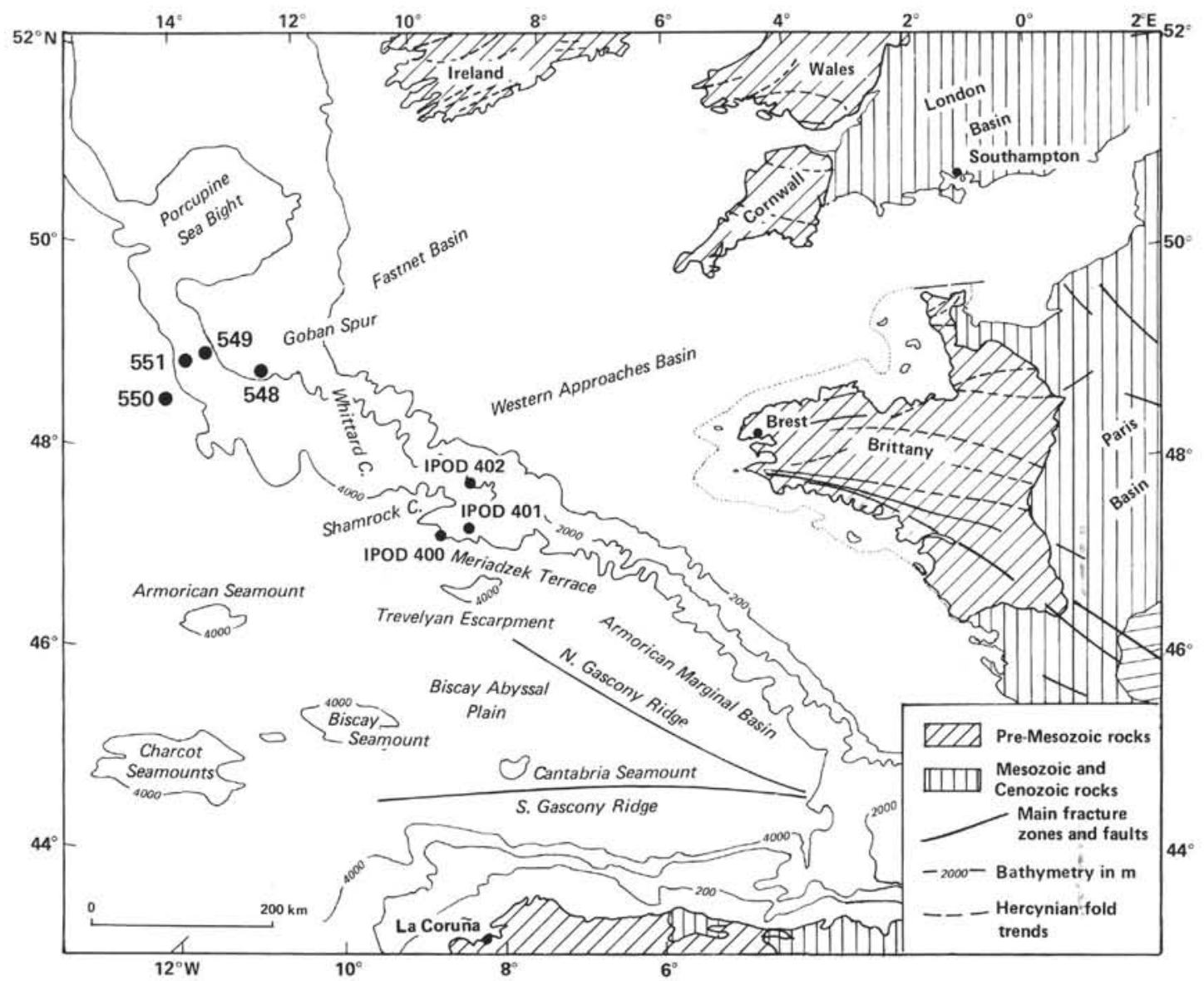

Figure 1. Map showing Goban Spur and DSDP drill sites. Bathymetry in meters.

ting" within a group can be accounted for by ecophenotypy. Only genera represented by abundant specimens (Figs. 3 and 4) have been used in our environmental analyses.

\section{GENERIC ASSEMBLAGE TRENDS}

In our samples, 102 genera were recognized; of these, 24 are represented by abundant specimens in one or more samples (Fig. 3). Bolivina is the most persistently abundant form throughout the sampled section. Cibicides and Cassidulina are prominent in most samples, and Bulimina and Uvigerina are abundant in more restricted intervals. Today, such assemblages are common in epibathyal depths around the Atlantic Basin, and have been documented in the vicinity of Site 548 by Pujos-Lamy (1973).

When the generic assemblages are analyzed stratigraphically, however, some distinctive changes can be seen (Fig. 3). The oldest significant change takes place near the unconformity that separates middle Miocene from upper Miocene sediments (between samples 14 and 15; Fig. 2). Here, Siphonina, generally abundant in the Oligocene, lower Miocene, and middle Miocene sections, disappears in sample 13 below the unconformity and is absent (except for a rare occurrence in sample 15) above the unconformity. Uvigerina also disappears across the unconformity, and Cibicides is diminished.
The N16/N17 boundary (samples 23/24) is marked by a reduction in Cassidulina and an increase in Uvigerina. Bolivina is temporarily reduced above the boundary, and Vulvulina increases. In contrast, at the Miocene/ Pliocene boundary (samples 34/35), Cassidulina increases and Uvigerina decreases. Both these genera, as well as Cibicides, decrease at the NN16/NN15 boundary (samples 51/52), and Sigmoilopsis increases two samples above it. The Pliocene/Pleistocene boundary (samples 56 and 57) is marked by an increase in Cassidulina, Trifarina, and Gavelinopsis.

Such fluctuations in the abundance of stratigraphically persistent forms have been shown to result from environmental changes (Miller et al., this vol.; Streeter, 1973; Schnitker, 1974; Lohmann, 1978; Douglas and Heitman, 1979; Caralp, this vol.). These changes will be assessed further in our discussion.

\section{GENERIC DIVERSITY TRENDS}

We have tabulated generic diversity (number of genera in a sample) throughout the studied interval, as shown in Figure 5. Generic diversity ranges from 20 to 42, and the mean value is 30 . If the variability about the mean is considered, 10 distinct intervals of consistently high or low values can be seen. The Oligocene section is characterized by low diversity. A significant shift to higher di- 


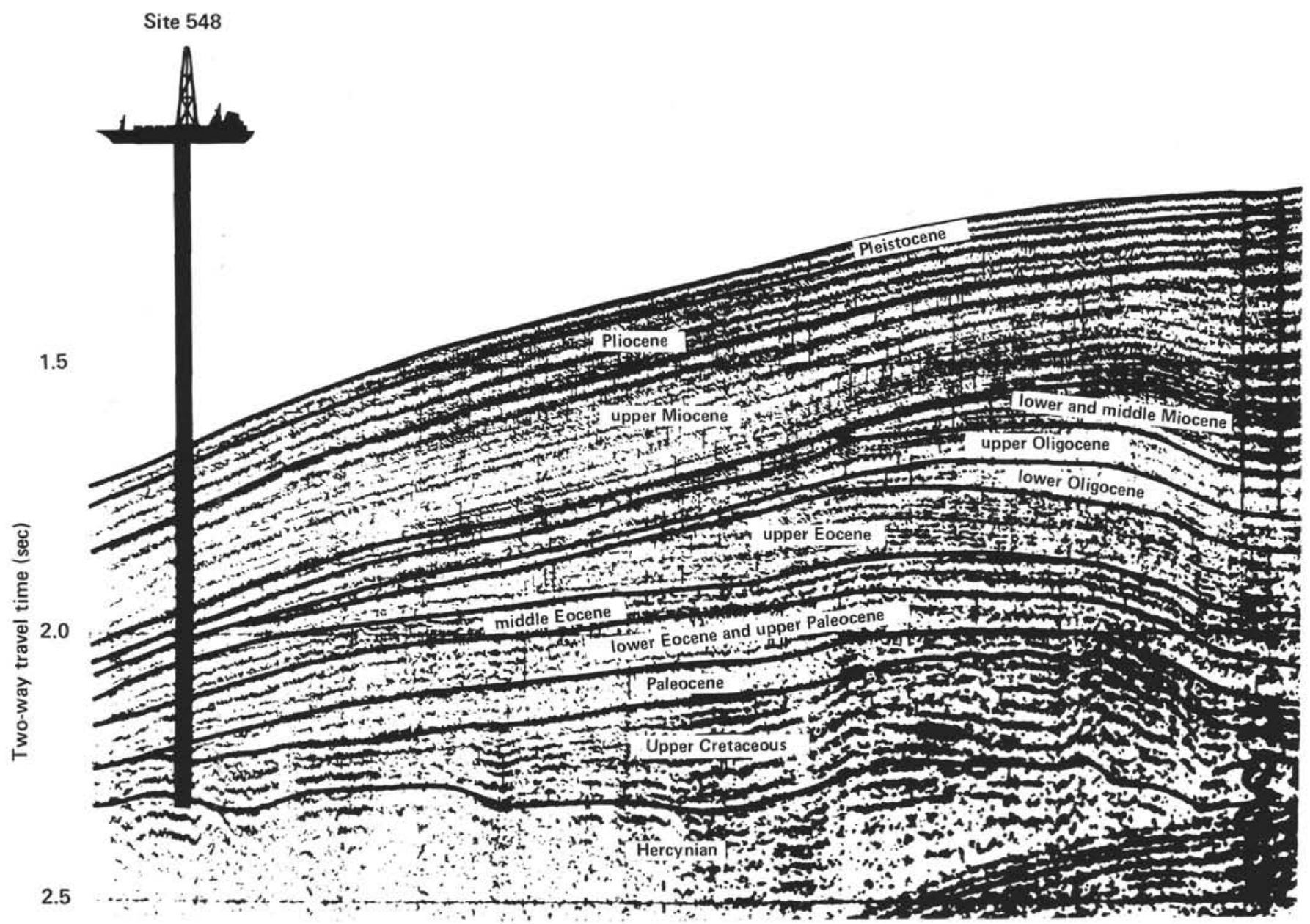

Figure 2. High-resolution seismic profile run by Glomar Challenger across Site 548 .

versity takes place across the Oligocene/Miocene boundary, and values remain generally higher than the mean throughout the lower and middle Miocene sections.

A major decrease to the lowest values recorded is associated with the middle Miocene/upper Miocene unconformity. Values lower than the mean are then maintained (three exceptions) through the lower third of planktonic foraminiferal Zone N17 (sample 27). Upsection, beginning in sample 28 , values increase above the mean, and are maintained (one exception) throughout the upper two thirds of Zone N17 (the remainder of the upper Miocene section).

A distinct decrease to values lower than the mean takes place across the Miocene/Pliocene boundary (samples $35 / 36$ ). Low values persist through sample 39 (into the lower part of calcareous nannofossil Zones NN12-NN15; sample 40). High values return for a short interval through sample 42. Above that, low values return and persist through sample 48 (one exception).

The uppermost parts of Zones NN12 through NN15 (samples 49-52) are characterized by high diversity. Most of Zones NN16 through NN18 contain low-diversity assemblages, but values increase dramatically again across the Pliocene/Pleistocene boundary.
A similar plot of species diversity values (number of species per sample) reveals almost identical diversity cycles. The only significant differences are that lower Oligocene species diversity is distinctly higher than the mean, and the low-value interval between samples 41 and 48 on the generic diversity curve is limited to samples 41 to 45 on the species diversity curve. The fluctuating manner of these diversity values is to be expected, as environments changed temporally on Goban Spur (Buzas and Gibson, 1969; Gibson and Buzas, 1973; Poag, 1981). We shall discuss further the implications of the diversity values for Site 548 .

\section{BOLIVINA ASSEMBLAGE TRENDS}

We have analyzed Bolivina more thoroughly at the species level (Fig. 4) because it is the most persistently abundant generic group throughout the Neogene interval at Site 548 , and is represented by more species in almost every sample than is any other genus. No attempt was made to identify the species by name, although several are well-known forms. We have illustrated them on Plates 1 and 2 so that interested readers may recognize their morphology. We have used a conservative approach to the species concept, including within some species 


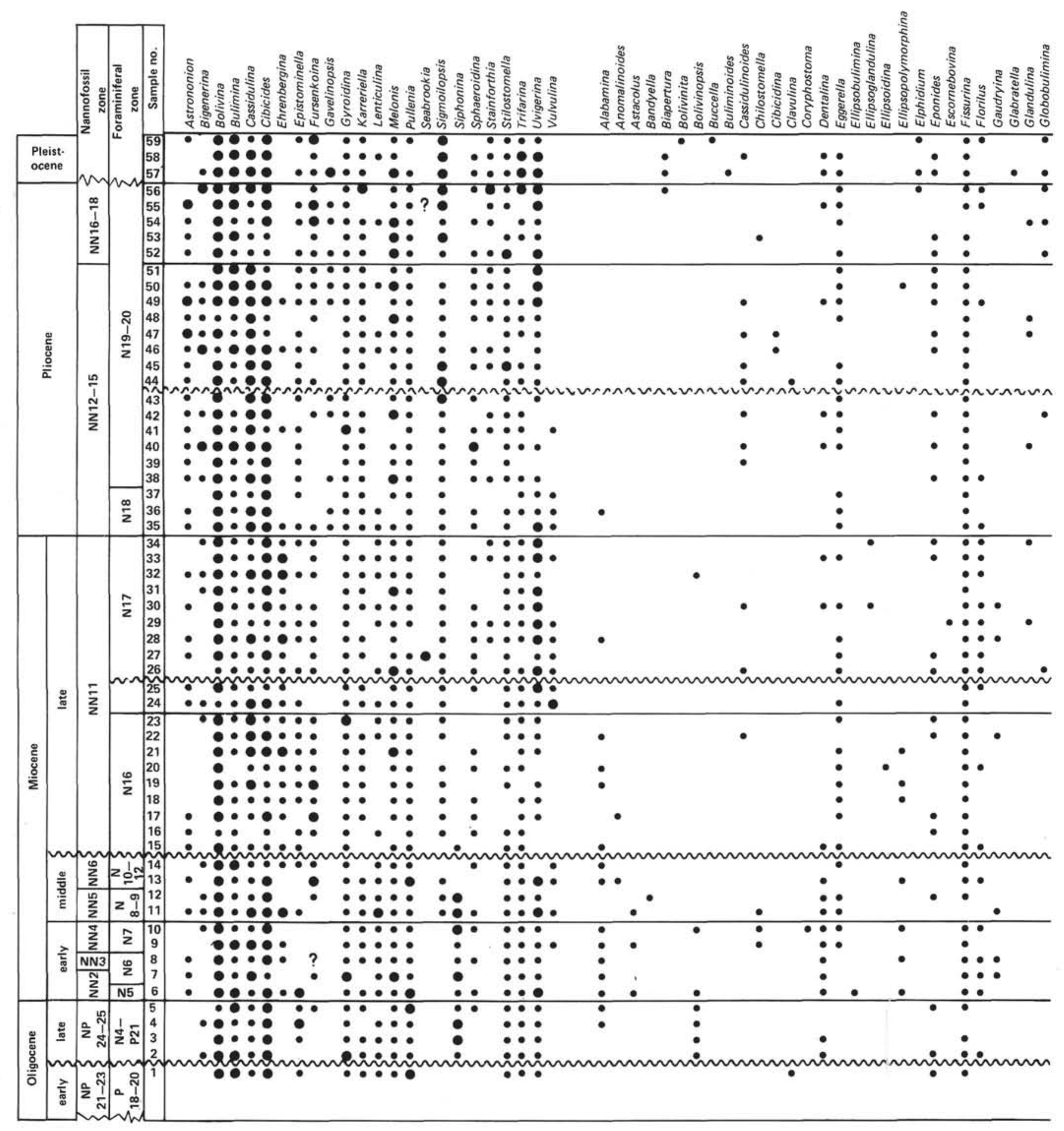

Figure 3. Presence/absence data for Neogene benthic foraminiferal genera at Site 548. (Samples 1-34 from Hole 548A; samples 35-59 from Hole 548; see Fig. 5 caption.) Small solid circles indicate specimens are present; large solid circles indicate specimens are abundant. Relative sea-level curve modified from Vail and Hardenbol, 1979.

several variants that may be either ecophenotypes or members of discrete evolutionary lineages. Some of this morphologic variability is illustrated on Plates 1 and 2.

The limited stratigraphic ranges of nearly all the species recognized are chiefly reflections of evolutionary change, but fluctuating abundances may be attributed almost wholly to environmental change (some sampling error may also be involved). Only those species that occur in abundance in several samples lend themselves to confident interpretation.

Change in the depositional environment is indicated at the Oligocene/Miocene boundary by several species. Species 3, for example is abundant in the Oligocene but absent in most of the lower and middle Miocene sec- 


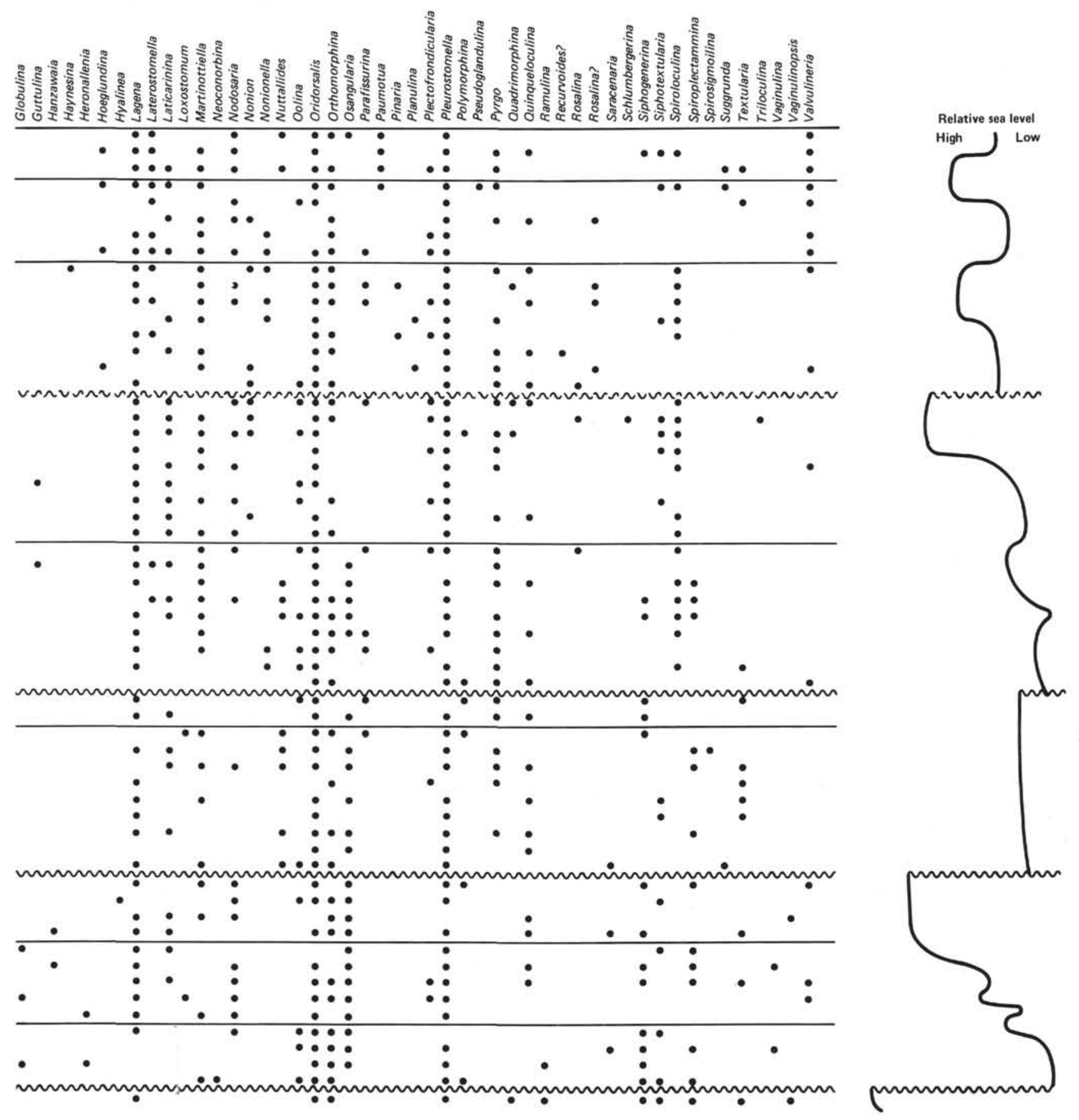

Figure 3. (Continued).

tion. Species 1 , consistently present (although in low numbers) in the Oligocene, also disappears temporarily just above the base of the Miocene. Species 7 is sparse in the Oligocene but persistently abundant in the lower Miocene.

An environmental change at the lower/middle Miocene boundary is indicated by an upsection increase in species 2 and 5 , and by the abrupt disappearance of species 7 . At the unconformity between the middle and up- per Miocene strata, species 2 is reduced, and species 13 becomes abundant for the first time.

Another environmental change is indicated just below the N16/N17 boundary by the upsection reduction of species 13. Its subsequent increase again in the middle of Zone N17 suggests another environmental shift, which is also reflected in the increase of species 2 .

No particular change is associated with the Miocene/ Pliocene boundary, but within the lower Pliocene (N18/ 


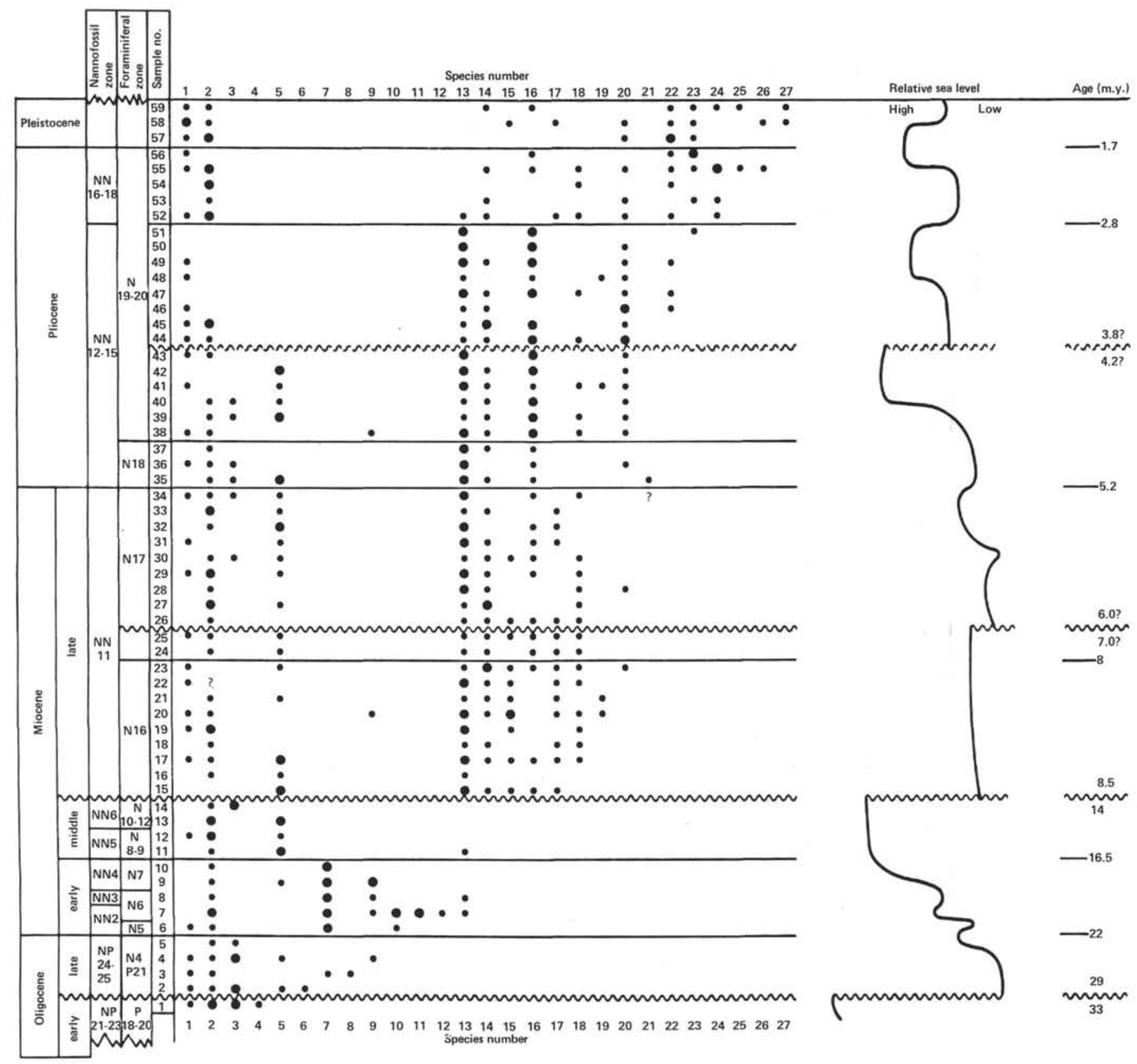

Figure 4. Presence/absence data for 27 Neogene Bolivina species recorded at Site 548. (Samples 1-34 from Hole 548A; samples 35-39 from Hole 548; see Fig. 5 caption.) Small solid circles indicate specimens are present; large solid circles indicate specimens are abundant. Relative sea-level curve modified from Vail and Hardenbol (1979). Planktonic foraminiferal zonation after Snyder (this vol.); nannofossil zonation after Müller (this vol.).

N19 boundary) a marked increase in species 16 is evidence of an environmental shift.

A disturbance in the middle Pliocene (middle of zonal interval NN12-NN15) is indicated between samples 42 and 45 , where species 2 and 5 disappear abruptly, species 13 is reduced, species 16 disappears temporarily, and species 14 and 20 experience short-term expansions.

At the NN15/NN16 boundary, species 2 appears again in abundance, and species 13 and 61 are severely reduced, signalling another environmental shift.

No major change is indicated at the Pliocene/Pleistocene boundary, but a subtle perturbation may be indi- cated by the upsection increase in species 22 and the accompanying reduction of species 23 .

\section{BOLIVINA DIVERSITY TRENDS}

Figure 5 contains a plot of species diversity (number of species per sample) for Bolivina throughout the Neogene section. The range of diversity is 2 to 12 , and the mean is 6 . If we observe the stratigraphic variation about the mean, we see four principal intervals of alternating high and low values. The Oligocene, lower Miocene, and middle Miocene assemblages are of low diversity (one exception greater than the mean). Just above the 
middle Miocene/upper Miocene unconformity, the values become generally higher than the mean (through sample 41; however, four short low-diversity increments are interspersed through this section, which constitutes the lower third of Pliocene Zones NN12-NN15). Throughout the upper part of the Pliocene and into the lower Pleistocene, diversity values are generally at mean value or higher.

These four main fluctuations can be subdivided into additional smaller increments by correlating with the finer-scale shifts in the generic and total species diversity curves. All these shifts in diversity appear to be related to environmental fluctuations, as shown in the discussion following.

\section{CORRELATIONS BETWEEN BIOTIC, PHYSICAL, AND GEOCHEMICAL FLUCTUATIONS AND ENVIRONMENTAL CHANGE}

In order to offer an interpretation of the kinds of environmental changes that took place at Site 548 during the Neogene, we have compared the three biotic diversity curves (Fig. 5) with a lithologic column, the downhole record of natural gamma-ray intensity, a plot of percent total organic carbon in the sediments, a sediment accumulation rate curve, and a modified version of the Vail and Hardenbol (1979) sea-level curve.

Variable intensities recorded by the gamma-ray log (GRL) generally reflect the relative amount of clay minerals in the sediments, as high gamma-ray intensities are measured in argillaceous intervals. For the Neogene of Site 548, highest GRL values are recorded in lithologies described as marly or sandy, where the grains include significant amounts of sand-sized foraminifers, and where carbonates are lithified into chalks. Obviously, however, the preliminary lithologic descriptions are not detailed enough to recognize all the high-intensity zones displayed on the GRL (see Fig. 5).

Total organic carbon (TOC) content, measured in percent, also can be used in a general way as an indication of the relative amount of terrigenous detritus being supplied to the site. The signal can be modified, however, by the rate of sediment accumulation and by microbial diagenesis (Waples, this vol.). In addition, a long-term decrease in TOC with depth is overprinted on the Site 548 record.

The sediment accumulation rate curve is useful in interpreting the positions of stratigraphic gaps, and indicates the effective balance between sediment deposition, erosion, and redistribution.

Diversity curves for genera and total species probably indicate relative physiochemical stability and rigor of the environment, higher diversities indicating greater stability and less rigor (Sanders, 1968; Bretsky and Lorenz 1970; Levinton, 1970, 1973, 1974; Grassle and Sanders, 1973; Somero and Soulé, 1974; Bernstein et al., 1978). Diversity fluctuations may indirectly reflect the change in water depth at Site 548, as deeper sites are generally more stable and less rigorous than shallow ones.

The diversity of Bolivina species appears to reflect the relative amount of organic carbon at the seafloor or in the sediments at the time of deposition, with high di- versities indicating higher percentages of organic carbon. Today, higher concentrations of Bolivina (and organic carbon) are intimately related to the position of the oxygen-minimum zone in the water column (Smith, 1963; Harman, 1964; Poag, 1981; Sen Gupta et al., 1981; Leutenegger and Hansen, 1979), to upwelling of nutrient-rich bottom waters (Phleger and Soutar, 1973; Sen Gupta et al., 1981), to delta-front substrates, and to regions of organic pollution (Casey et al., 1981). We use high Bolivina species diversity to indicate the presence of an oxygen minimum at Site 548. There is no good evidence for delta-building or pollution, and the additional sedimentary characteristics associated with upwelling (Diester-Haass, 1978) have not been observed. At present, Site 548 lies beneath a water mass consisting chiefly of Mediterranean Outflow Water (MOW), which creates an oxygen minimum of 4.0 to $4.8 \mathrm{ml} / 1$ between 300 and $1500 \mathrm{~m}$ (Reid, 1979), coincident with the zone of maximum Bolivina abundance and species diversity (PujosLamy, 1973). Below $1500 \mathrm{~m}$, a more oxygen-rich, nutrient-poor water mass, similar to North Atlantic Deep Water (NADW), is present.

All the measured properties that we have cited can be influenced in relatively shallow sites like Site $548(1246 \mathrm{~m})$ by sea-level fluctuations and accompanying water-mass changes, be they of eustatic or local origin. These relationships are considered in the following discussion, in which we have used the gamma-ray log to separate the sediment section into stratigraphic levels and intervals (Fig. 5).

\section{Below GLR Level 1}

The upper Oligocene section (Fig. 5) consists of foraminiferal and nannofossil chalks that accumulated slowly $(3 \mathrm{~m} / \mathrm{m} . \mathrm{y}$.$) , contain very little TOC (0.0-0.05 \%)$, and produce low gamma-ray intensities. The benthic foraminiferal assemblage is dominated by Bolivina, Cibicides, Bulimina, and Siphonina. The diversities of genera, total species, and Bolivina species are low. These properties suggest that deposition took place in a well-oxygenated epibathyal biotope (water mass similar to NADW) where little terrigenous sediment was accumulating. It was a period when sea level was low but gradually rising (Vail and Hardenbol, 1979).

\section{GRL Level 1}

At GRL level 1, a small gamma-ray intensity peak indicates a substrate change at the Oligocene/Miocene boundary, although no significant change was noted in lithology, sediment accumulation rate, or TOC content. However, an environmental change is indicated by significant increases in generic and total species diversities, and by abundance changes among 5 species of Bolivina.

\section{GRL Interval 1-2}

Between GRL levels 1 and 2, the nannofossil chalk becomes coarser-grained by addition of abundant planktonic foraminifers. The TOC content increases to a range of 0.05 to $0.10 \%$, but no significant change takes place in sediment accumulation rate. Predominant genera are Bolivina, Cibicides, Bulimina, Cassidulina, and Siphonina. Generic and total species diversities are consistent- 

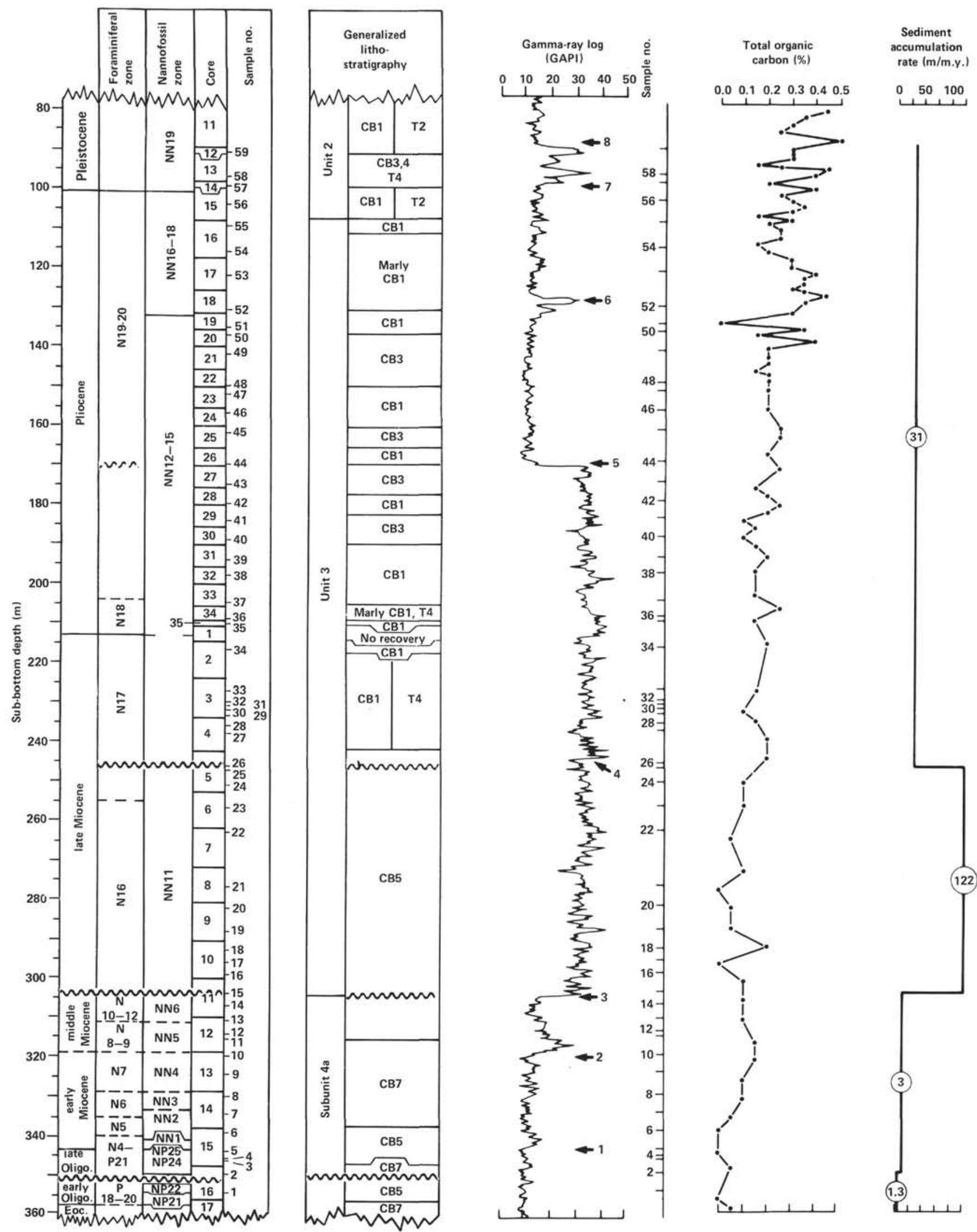

Figure 5. Comparison of Neogene lithology, gamma-ray intensity, total organic carbon, sediment accumulation rate, generic diversity, total species diversity, and Bolivina species diversity, with sea-level curve. Vertical lines in columns for generic diversity, total species diversity, and Bolivina species diversity indicate the mean number of taxa. Relative temperatures indicated beside the sea-level curve are based on study of calcareous nannofossils (analyzed by Müller, this vol.). Numbered levels on gamma-ray curve are discussed in text. (Cores 1-17 at bottom [samples 1-34], Hole 548A; Cores 11-34 at top [samples 35-39], Hole 548.) Lithologic symbols are as defined in Explanatory Notes (this vol.). 
ENVIRONMENTAL TRENDS AMONG NEOGENE BENTHIC FORAMINIFERS
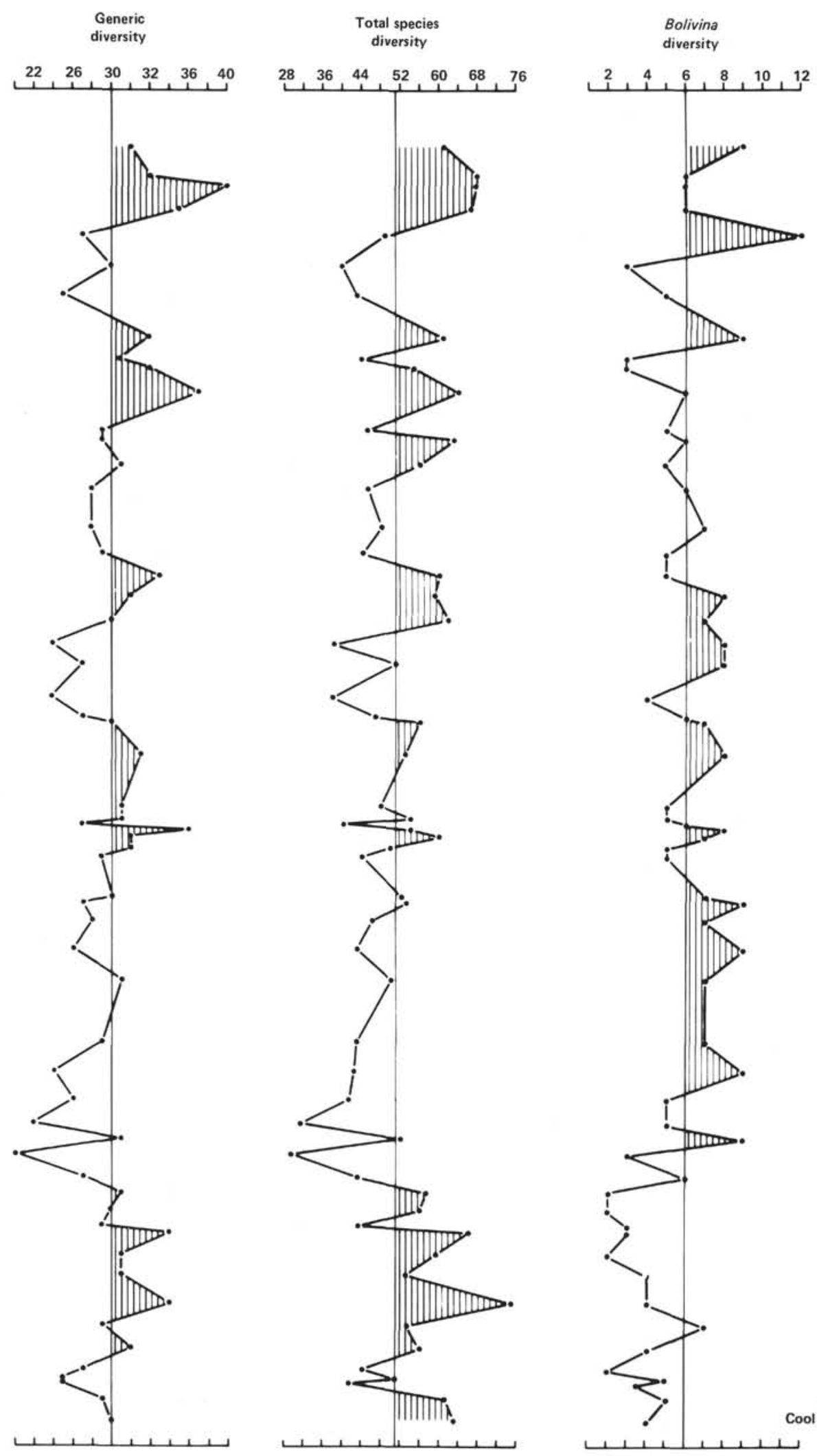

Sea level
(modified from Vail
and Hardenbol,1979)

High Low
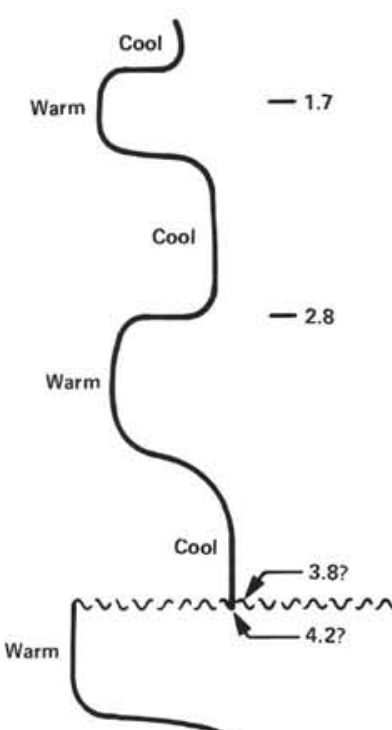

Figure 5. (Continued). 
ly above the mean, but Bolivina species diversity remains lower than the mean. These properties indicate that deposition took place in a well-oxygenated epibathyal environment (still beneath a NADW-like water mass) in which terrigenous detritus was a minor, but increasingly more important, increment of a chiefly pelagic sedimentary regime. It corresponds to a period when sea level was slowly rising in distinct pulses (Vail and Hardenbol, 1979).

\section{GRL Level 2}

At this level another high-intensity gamma-ray peak, accompanied by a small peak in TOC content, signals a pulse of terrigenous detrital deposition across the lower Miocene/middle Miocene boundary. Abundance shifts take place in several genera, and are accompanied by major peaks in generic and total species diversities.

\section{GRL Interval 2-3}

Between GRL levels 2 and 3, gamma-ray intensity is low, and the sediment is chiefly slowly accumulated nannofossil chalk containing 0.10 to $0.15 \%$ TOC. Predominant genera are Bolivina, Cibicides, Siphonina, and Uvigerina. Diversities of genera and total species are generally high, but decline upsection, whereas Bolivina species diversity is consistently at the lowest values measured. These properties suggest that deposition took place in environments nearly identical to those of the GRL 1-2 interval. The GRL 2-3 interval accumulated during a period of stable high sea level (Vail and Hardenbol, 1979).

\section{GRL Level 3}

At this level a major shift to persistently high gamma-ray intensities marks the middle Miocene/upper Miocene unconformity. Accumulation rate increases dramatically to $122 \mathrm{~m} / \mathrm{m} . \mathrm{y}$., accompanied by a slight change in lithology, but no change in TOC content was measured. Several changes in abundance and diversity of benthic foraminifers at this level have already been noted. The unconformity is an erosional one, as indicated by the nature of the contact (Poag et al., this vol.; Fig. 6), and may have resulted from at least two periods of low sealevel disturbance (Vail and Hardenbol, 1979).

\section{GRL Interval 3-4}

Between GRL levels 3 and 4, gamma-ray intensities are consistently high, although considerable variability is recorded. The sediment is dominantly nannofossil chalk, and TOC content is generally low $(0.0-0.1 \%)$, but accumulation rate is the highest recorded for the $\mathrm{Ne}$ ogene at this site $(122 \mathrm{~m} / \mathrm{m} . \mathrm{y})$. Predominant genera are Bolivina, Cibicides, and Cassidulina. Generic and total species diversities are low, but show an upsection trend toward gradually increasing values. Bolivina species diversity for the first time reaches values consistently above the mean. These properties indicate that deposition took place in an epibathyal environment characterized by the presence of an oxygen-minimum zone. This may have been brought about by depression of the NADW-like water mass during this extended period of low sea level (Vail and Hardenbol, 1979), and by its replacement by a
MOW-like water mass, a condition similar to the present one at Site 548 .

\section{GRL Level 4}

At this level a significant gamma-ray intensity peak marks an upsection increase in terrigenous detritus (graded beds of sandy [quartz, glauconite] marly ooze, presumably of turbidity-current origin) and a major reduction in sediment accumulation rate to $31 \mathrm{~m} / \mathrm{m}$.y. These changes are accompanied by a distinctive rounded peak $(0.2 \%)$ on the TOC curve. A corresponding erosional unconformity was cored and recovered in Sample 548A-5-3, $50-51 \mathrm{~cm}$ (between our samples 25 and 26; Fig. 6). Using the time scale and sea-level curve of Vail and Hardenbol (1979), the hiatus represented by this unconformity can be estimated to be $\sim 1.3 \mathrm{~m}$.y. It is presumed to correlate with the sea-level drop $\sim 6.6 \mathrm{~m}$.y. ago.

\section{GRL Interval 4-5}

Between GRL levels 4 and 5, gamma-ray intensities remain generally high (with considerable variability), rate of sediment accumulation remains low, and TOC content is rather stable at 0.1 to $0.2 \%$, but at least three distinct faunal and lithologic intervals can be noted.

The lowest of these three intervals is the Messinian Stage, which contains the greatest enrichment in terrigenous debris (samples 28-35). All three diversity curves display principally lower-than-mean values. The predominant genera are Bolivina, Cibicides, and Uvigerina, and species 2, 5, and 13 are predominant among Bolivina specimens. These properties suggest that deposition took place in epibathyal depths within an oxygen-enriched zone, in biotopes regularly receiving a contribution of terrigenous debris through turbidity currents. The Messinian was a time of generally low sea level, when the Mediterranean was completely cut off from its Atlantic connection (Hsü et al., 1977), thus stopping the flow of low-oxygen MOW. The shallow waters apparently become enriched in oxygen during this unusual period.

In the lowermost Pliocene (samples 36-39), the sediments are chiefly nannofossil ooze. No significant subdivisions of the gamma-ray curve can be distinguished, and TOC content hovers between 0.15 and $0.25 \%$. Generic and total species diversities decrease significantly. Bolivina species diversity also decreases markedly in the lower part of this interval (samples 36 and 37), but is high again in the upper part (samples 38 and 39). Uvigerina is no longer a predominant form, but Bolivina and Cibicides persist in abundance, joined again by abundant Cassidulina. Bolivina species 16 becomes abundant for the first time in sample 38, and remains persistently so throughout most of the rest of the Pliocene. These properties suggest that deposition continued in epibathyal depths. Sea level was low, but few terrigenous particles reached the site. The oxygen minimum was absent at the site during deposition of the lower part of this interval, but returned as the upper part accumulated while the Mediterranean and Atlantic were reconnected and MOW again influenced the site.

In the upper third of GRL interval 4-5 (samples 4042), the sediment coarsens with addition of abundant planktonic foraminifers, and TOC content increases to 


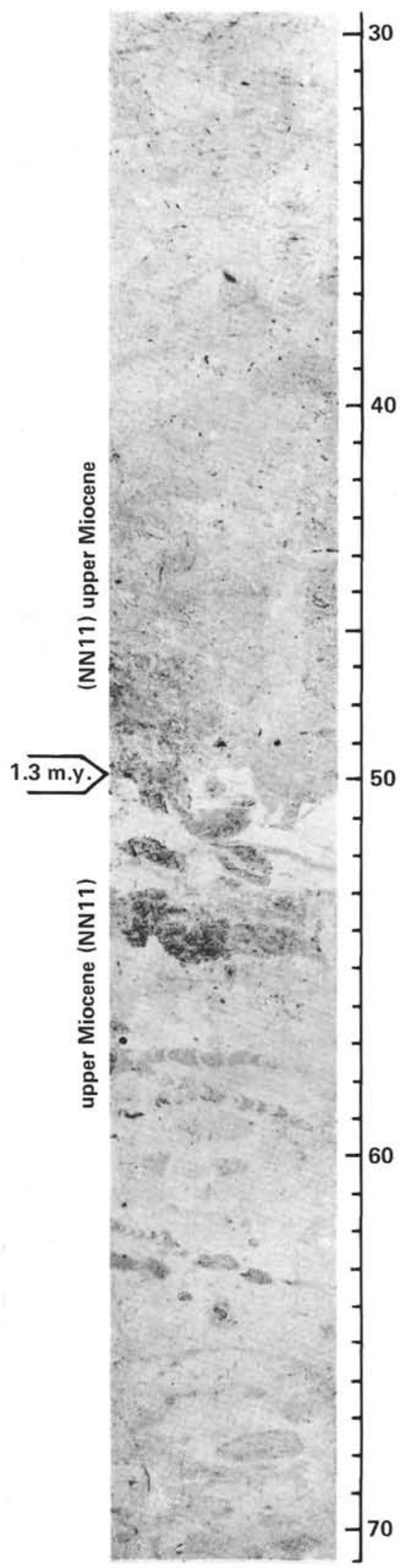

Section 548A-5-3

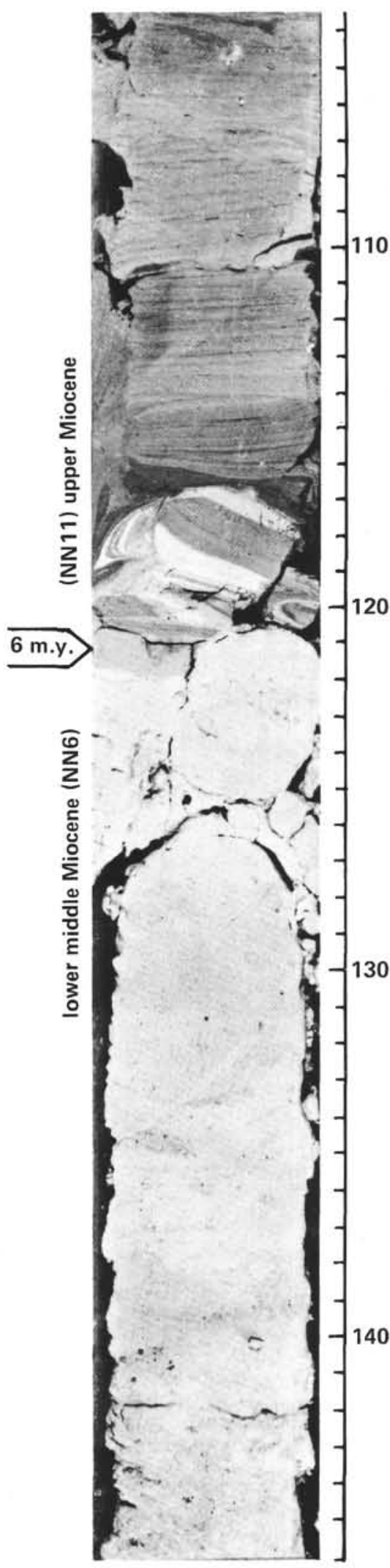

Section 548A-11-3

Figure 6. Two major Neogene unconformities documented at Site 548. Numbers in brackets at left of each column mark the unconformity and indicate the time of the hiatus in m.y. NN designations are Neogene nannofossil zones derived from Müller (this vol.). Vertical scale records $\mathrm{cm}$ below the top of the core section. 
between 0.2 and $0.25 \%$. Bolivina, Cibicides, and Cassidulina remain the predominant genera. Initially, diversities of genera and total species increase significantly, and Bolivina species diversity remains high, but all values decrease between samples 42 and 44 . These properties suggest that deposition continued in an epibathyal low-oxygen environment, far from terrigenous influence, as sea level began to rise. But when sea level reached a high position around 4.2 to $4.4 \mathrm{~m} . \mathrm{y}$ ago, the NADWlike water mass covered the site again, reducing the Bolivina community and creating unstable environments.

\section{GRL Level 5}

At this level gamma-ray intensity drops precipitously, although lithologic change is subtle, involving only a variable component of planktonic foraminifers. However, a small peak in TOC content $(0.25 \%)$ corresponds to the GRL break. Several faunal changes take place one sample below this intensity drop, but uncertainties of correlation between the incompletely recovered cores and the GRL are such that sample 43 may actually correspond to level 5. Diversities of genera, total species, and Bolivina species decrease abruptly, Sigmoilopsis becomes abundant for the first time, Bolivina species 5 disappears suddenly, species 13 is reduced, and species 20 is abundant for the first time. These events suggest that GRL level 4 marks an unconformity that formed when sea level dropped between 3.8 and $4.2 \mathrm{~m}$.y. ago (Vail and Hardenbol, 1979). Recovery of cores in this interval was too incomplete for precise identification of the position of the unconformity within the cores, but it can be tentatively placed between Cores 548-26 and 548-27.

\section{GRL Interval 5-6}

The interval between GRL 5 and 6 is characterized by consistently low gamma-ray intensities and alternating nannofossil and foraminiferal nannofossil oozes. The TOC content and faunal diversity indicate a twofold subdivision of this interval. In the lower half (samples 4448), generic and Bolivina species diversities are generally low. Total species diversity starts out low, also, but increases significantly in samples 46 and 47 before dropping again in sample 48. Predominant genera are Bolivina, Cibicides, and Cassidulina. Sigmoilopsis is abundant in the three lowest samples, and Bolivina species 13 is generally reduced throughout the interval. The TOC content stays consistently at 0.2 to $0.25 \%$. These conditions appear to represent deposition in unstable epibathyal biotopes that accompanied a slow sea-level rise. The site was relatively isolated from terrigenous influences, and the bottom was well oxygenated by NADWlike water.

Beginning with sample 49 , diversities of genera and species increase upsection, suggesting general stability associated with a period of high-standing sea level. Continued low diversity of Bolivina species suggests that relatively high oxygen contents prevailed in NADW-like bottom waters. The TOC content fluctuates widely in this interval. Bulimina and Uvigerina become important constituents of the benthic generic assemblage, and Bolivi$n a$ species 13 returns in abundance.

\section{GRL Level 6}

The sharp intensity peak at GRL level 6 signals injection of a significant component of terrigenous clays to form a marly nannofossil ooze. A major increase in TOC content to between 0.3 and $0.45 \%$ also reflects the flood of terrigenous detritus at approximately the boundary between nannofossil Zones NN15 and NN16. Benthic foraminifers responded to this deposition with increased diversity of Bolivina species and a reduction in Cassidulina, Cibicides, and Bolivina species 13 and 16 . Bolivina species 2 returned in abundance. This suggests a major fall of sea level ( $2.8 \mathrm{~m} . \mathrm{y} . \mathrm{ago})$ and a return of an oxygen-minimum layer to the site.

\section{GRL Interval 6-7}

This interval is characterized by a return of low gamma-ray intensities and continued accumulation of terrigenous debris. The interval can be divided into three parts by TOC and faunal changes. In the lower half (samples 53-55), generic, total species, and Bolivina species diversities diminish, followed in the next sample upsection by a drop in TOC. Uvigerina is reduced compared with the previous interval, but the predominance trend among the remaining genera is the same. Bolivina species 2 increases abruptly and remains abundant. These characteristics suggest that sea level remained low, allowing an abundant contribution of terrigenous detritus, but shifting water masses created a well-oxygenated epibathyal biotope.

In the upper part of GRL interval 6-7 (samples 56 and 57), rapidly increasing generic and total species diversities indicate the stabilizing effects of high sea level, but terrigenous components continued to reach the site, and TOC contents remain generally around $0.3 \%$. Fluctuations in diversity of Bolivina species again indicate independent movement of the oxygen-minimum zone.

\section{GRL Levels 7 and 8}

Two prominent, closely spaced gamma-ray intensity peaks at GRL levels 7 and 8 are mimicked on the TOC content curve, where peaks of 0.4 and $0.5 \%$ are the highest values measured in the studied interval. The sediments are enriched in muds and silty sands of terrigenous origin. Level 7 marks the Pliocene/Pleistocene boundary. An abundant benthic assemblage contains predominantly Bolivina, Cibicides, Bulimina, Cassidulina, Sigmoilopsis, and Uvigerina, and abundance changes in Bolivina species 2, 22, and 23 are notable. Generic diversity is higher than the median value, but decreases markedly in the upper half of the interval. Total species diversity is also high, and shows a lagging decrease in the uppermost sample. The Bolivina species diversity curve is the inverse of the generic diversity curve.

These properties suggest that a stable environment deteriorated as sea level dropped across the Pliocene/ Pleistocene boundary and terrigenous deposits reached the site in abundance. The oxygen minimum was absent at the base of the interval, but as the shoreline stabilized in a seaward position, the oxygen minimum of the MOWlike water mass again covered the site. 


\section{SUMMARY AND CONCLUSIONS}

Evidence gathered in this study shows that generic and species diversity values and estimated generic abundance can be used to identify environmental changes recorded in Neogene marine sediments, and that they are particularly useful with regard to Site 548 . When these values are compared against geophysical, geochemical, and lithologic data, a pattern of alternating high and low sea levels emerges that correlates remarkably well with sea-level curves postulated by Vail and Hardenbol (1979). Site 548 remained in epibathyal depths on a tectonically passive margin as the accumulating sediment record monitored oceanographic and climatic changes of regional and global extent. An additional analysis of Bolivina species diversity and abundance has improved and corroborated the initial environmental interpretation, and provides in addition an indirect means of estimating fluctuation of the oxygen-minimum zone as the boundary between a MOW-like water mass and an NADW-like water mass shifted repeatedly above and below Site 548.

The studied record contains evidence that five periods of low sea level alternated with five periods of high sea level during late Oligocene to early Pleistocene deposition on upper Goban Spur. The sediment column is interrupted at three levels ("middle" Oligocene; middle and upper Miocene; upper Miocene) by unconformities associated with low sea levels and the shifting watermass interface. These unconformities were recovered in cores at Site 548. A fourth unconformity in the middle Pliocene is indicated by geophysical and faunal evidence, but was not recovered.

Thus, Site 548 experienced a continuously variable environment during the Neogene, in which the continental slope was gradually built up by complex interplay of pelagic carbonate and terrigenous detrital deposition, modulated and interrupted by fluctuation of sea level, shifting of water-mass boundaries, and associated submarine disturbances. Correlation of climatic cycles with this process can be seen by the fact that relative surfacewater temperatures, as estimated from a census of calcareous nannofossils, vary from warm to cold almost precisely in rhythm with sea-level cycles (Fig. 5; Müller, this vol.).

\section{REFERENCES}

Bernstein, B. B., Hessler, R. R., Smith, R., and Jumars, P. A., 1978. Spatial dispersion of benthic foraminifera in the abyssal central North Pacific. Limnol. Oceanogr., 23:401-416.

Bretsky, P. W., and Lorenz, P. W., 1970. Adaptive response to environmental stability: a unifying concept in paleoecology. Proc. $N$. Am. Paleontol. Conv. Part E, pp. 522-550.

Buzas, M. A., and Gibson, T. G., 1969. Species diversity: benthonic foraminifera in western North Atlantic. Science, 163:72-75.

Casey, R., Hueni, C., and Leavesley, A., 1981. Brizalina lowmani, a meroplanktonic foraminiferan useful as an indicator of shelfal circulation and eutrophication (with comments on biostratigraphy and evolution). Gulf Coast Assoc. Geol. Soc. Trans., 31:249-255.

Diester-Haass, L., 1978. Sediments as indicators of upwelling. In Boje, R., and Tomczak, M. (Eds.), Upwelling Ecosystems: New York (Springer-Verlag), pp. 261-281.

Douglas, R. G., and Heitman, H. L., 1979. Slope and basin benthic foraminifera of the California Borderland. In Doyle, L. J., and
Pilkey, O. H., (Eds.), Geology of Continental Slopes. Soc. Econ. Paleontol. Mineral. Spec. Publ., 27:231-246.

Erez, J., and Gill, D., 1977. Multivariate analysis of biogenic constituents in Recent sediments off Ras Burka Gulf of Elat, Red Sea. Math. Geol., 9:77-98.

Gibson, T. G., and Buzas, M. A., 1973. Species diversity: patterns in modern and Miocene foraminifera of the eastern margin of North America. Geol. Soc. Am. Bull., 84:217-238.

Grassle, J. F., and Sanders, H. L., 1973. Life histories and the role of disturbance. Deep Sea Res., 29:643-659.

Harman, R. A., 1964. Distribution of foraminifera in the Santa Barbara Basin, California. Micropaleontology, 10:81-96.

Hsü, K. J., Montadert, L., Bernoulli, D., Cita, M. B., Erickson, A., Garrison, R. E., Kidd, R. B., Mélières F., Müller, C., and Wright, R., 1977. History of the Mediterranean salinity crisis. Nature, 267: 399-403.

Leutenegger, S., and Hansen, H. J., 1979. Ultrastructural and radiotracer studies of pore function in foraminifera. Mar. Biol., 54: 11-16.

Levinton, J. S., 1970. The paleoecological significance of opportunistic species. Lethaia, 3:69-78.

, 1973. Genetic variation in a gradient of environmental variability: Marine Bivalvia (Mollusca). Science, 180:75-76.

1974. Trophic group and evolution in bivalve molluscs. $\mathrm{Pa}$ leontology, 7:579-585.

Lohmann, G. P., 1978. Abyssal benthonic foraminifera as hydrographic indicators in the western South Atlantic Ocean. $J$. Foraminif. Res., 8:6-34.

Phleger, F. B, and Soutar, A., 1973. Production of foraminifera in three east Pacific oxygen minima. Micropaleontology, 19:110-115.

Poag, C. W., 1981. Ecologic Atlas of Benthic Foraminifera of the Gulf of Mexico: Stroudsburg, PA (Hutchinson and Ross Publ.).

Pujos-Lamy, A., 1973. Répartition bathymètrique des foraminifères benthiques profounds du Golfe de Gascogne: comparaison avec d'autres aires océaniques. Rev. Espan. Micropaleontol., 5:213-234.

Reid, J. L., 1979. On the contribution of the Mediterranean Sea outflow to the Norwegian-Greenland Sea. Deep Sea Res., 26: 1199-1223.

Roberts, D. G., Masson, D. G., Montadert, L., and de Charpal, O., 1981. Continental margin from the Porcupine Seabight to the Armorican Marginal Basin. Proc. Conf. Petrol. Geol. Cont. Shelf North-West Europe, pp. 455-473.

Roberts, D. G., and Montadert, L., 1979. Evolution of passive rifted margins-perspective and retrospective of DSDP Leg 48. In Montadert, L., Roberts, D. G., et al., Init. Repts. DSDP, 48: Washington (U.S. Govt. Printing Office), 1143-1153.

Sanders, H. L., 1968. Marine benthic diversity: a comparative study. Am. Naturalist, 102:243-282.

,1969. Benthic marine diversity and the stability-time hypothesis. Brookhaven Symp. Biol., 22:71-81.

Schnitker, D., 1974. West Atlantic abyssal circulation during the past 120,000 years. Nature, 248:385-387.

1979. Cenozoic deep water benthic foraminifers, Bay of Biscay. In Roberts, D. G., Montadert, L., et al., Init. Repts. DSDP, 48: Washington (U.S. Govt. Printing Office), 377-389.

Sen Gupta, B. K., Lee, R. F., and May, M. S., III, 1981. Upwelling and an unusual assemblage of benthic foraminifera on the northern Florida continental slope. J. Paleontol., 55:853-857.

Smith, P. B., 1963. Quantitative and qualitative analysis of the family Bolivinitidae. U.S. Geol. Survey Prof. Paper, 429-A.

Somero, G. N., and Soulé, M., 1974. Genetic variation in marine fishes as a test of the niche-variation hypothesis. Nature, 249:670-672.

Streeter, S. S., 1973. Bottom water and benthonic foraminifer in the North Atlantic-glacial-interglacial contrasts. Quat. Res., 3: 131-141.

Vail, P. R., and Hardenbol, J., 1979. Sea-level changes during the Tertiary. Oceanus, 22:71-79.

Walton, W. R., 1964. Recent foraminiferal ecology and paleoecology. In Imbrie, J., and Newall, N. (Eds.), Approaches to Paleoecology: New York (Wiley), pp. 151-237.

Date of Initial Receipt: May 23, 1983

Date of Acceptance: November 22, 1983 


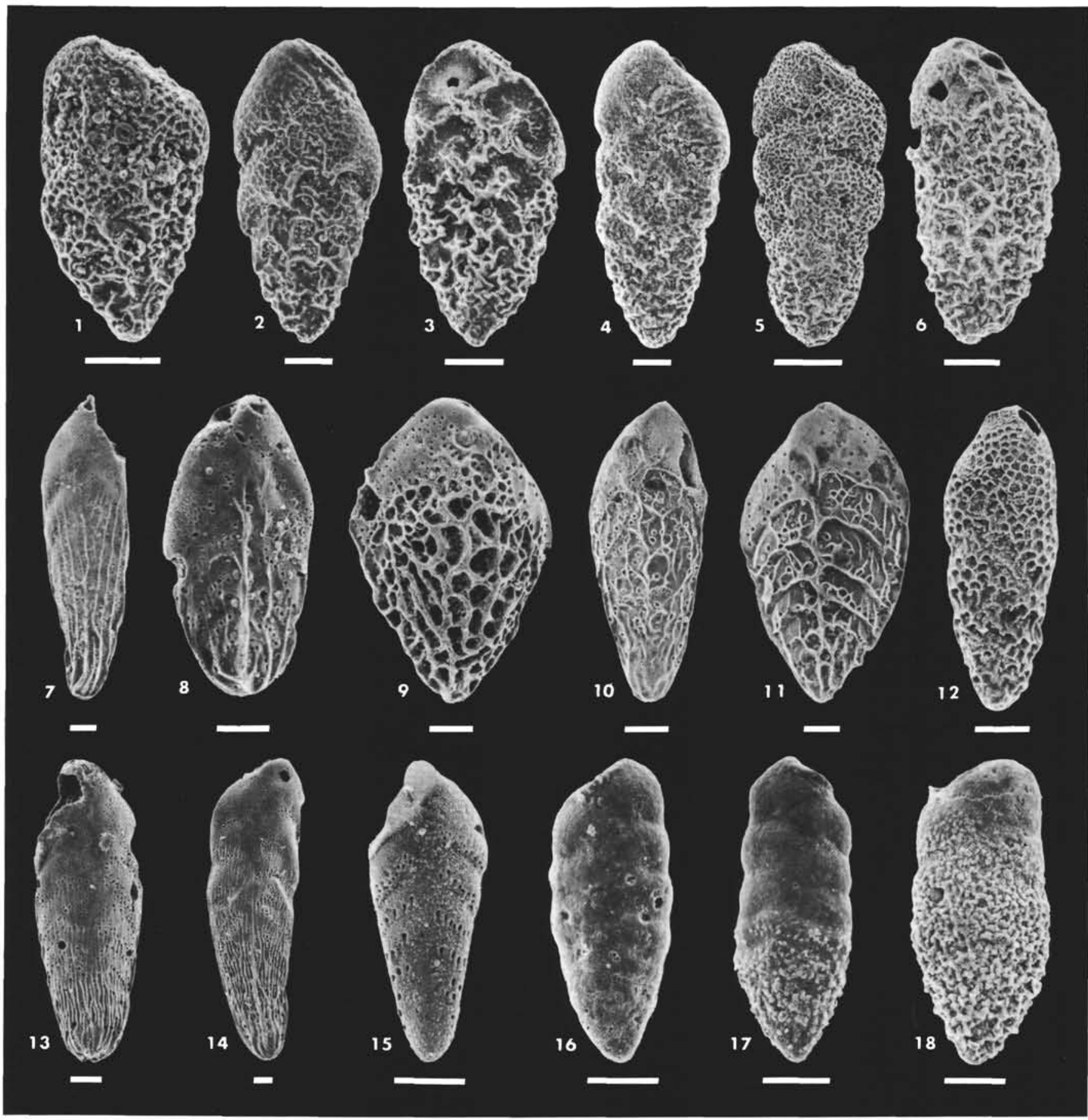

Plate 1. Neogene bolivinids from Site 548. (Bar scale $=50 \mu \mathrm{m}$.) 1. Bolivina $\mathrm{sp} .1$, Sample $548 \mathrm{~A}-16-5,87-89 \mathrm{~cm}$. 2-6. Bolivina sp. 2, (2) Sample 548A-16-5, 87-89 cm, (3) Sample 548A-12-3, 58-62 cm, (4) Sample 548A-9-5, 37-39 cm, (5) Sample 548A-15-5, 133-135 cm, (6) Sample 548A-3-4, 126-129 cm. 7. Bolivina sp. 3, Sample 549A-16-5, 87-89 cm. 8. Bolivina sp. 4, Sample 548A-16-5, 87-89 cm. 9-11. Bolivina sp. 5, (9) Sample 548A-15-5, 125-127 cm, (10) Sample 548A-3-5, 93-96 cm, (11) Sample 548A-12-4, 69-71 cm. 12. Bolivina sp. 10, Sample 548A-15-1, 81-83 cm. 13-14. Bolivina sp. 7, (13) Sample 548A-15-5, 133-135 cm, (14) Sample 548A-15-1, 81-83 cm. 15. Bolivina sp. 8, Sample 548A-15-5, 133-135. 16-18. Bolivina sp. 9, all from Sample 548A-13-4, 55-57 cm. 


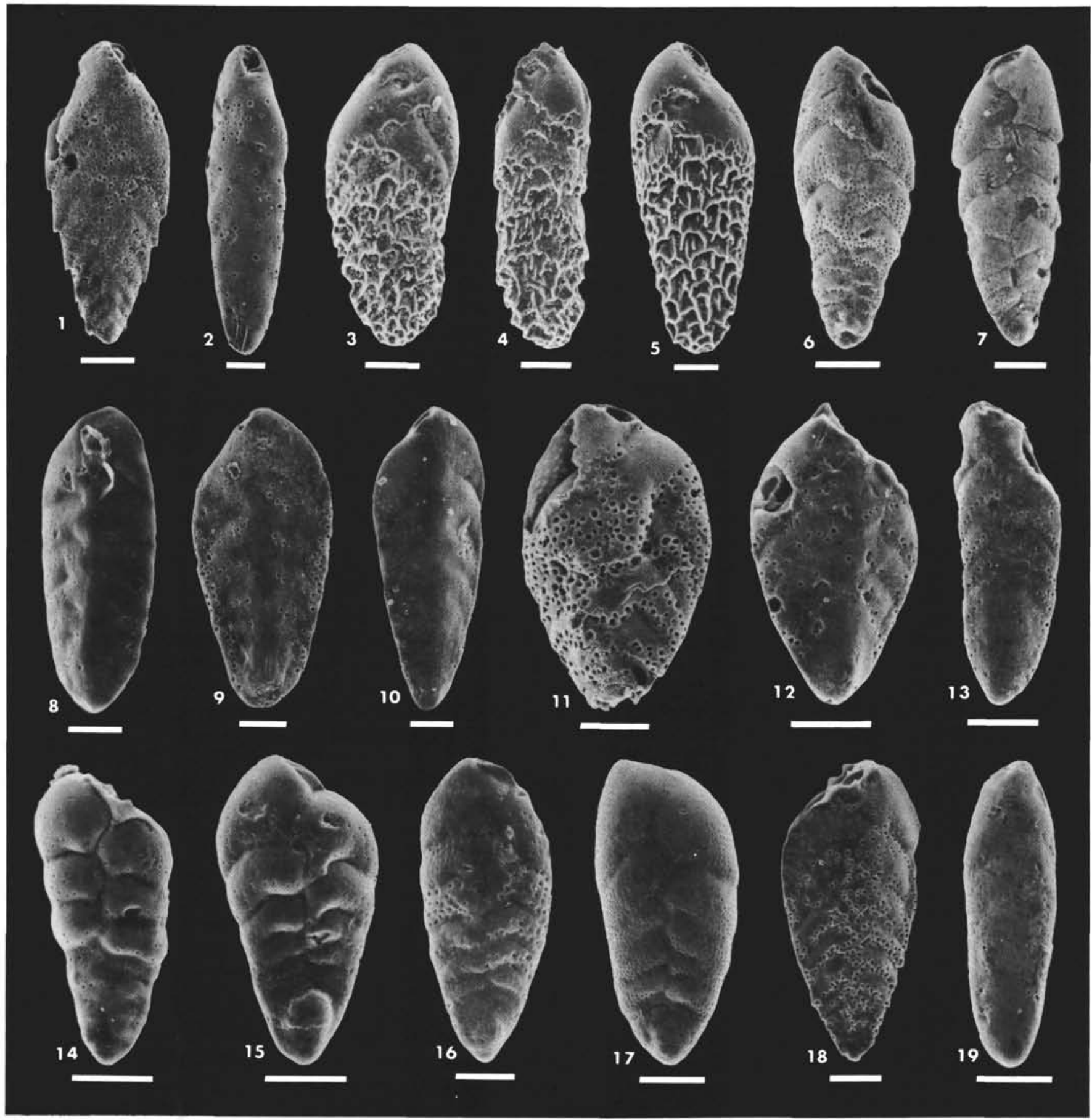

Plate 2. Neogene bolivinids from Site 548. (Bar scale $=50 \mu \mathrm{m}$.) 1. Bolivina sp. 11, Sample 548A-10-4, 76-78 cm. 2. Bolivina sp. 12, Sample 548A-10-4, 76-78 cm. 3-5. Bolivina sp. 13, (3-4) Sample 548A-11-3, 45-48 cm, (5) Sample 548-19-3, 117-120 cm. 6-7. Bolivina sp. 15, Sample 548A-9-1, 52-54 cm. 8. Bolivina sp. 14, Sample 548-26-3, 124-127 cm. 9-10. Bolivina sp. 16, (9) Sample 548A-3-6, 130-138 cm, (10) Sample 548-19-3, 117-120 cm. 11. Bolivina sp. 17, Sample 548A-3-5, 93-96 cm. 12. Bolivina sp. 18, Sample 548-3-4, 126-129 cm. 13. Bolivina sp. 19, Sample 548A-11-3, 45-48 cm. 14-16. Bolivina sp. 20, (14) Sample 548-34-2, 147-150 cm, (15-16) Sample 548-26-3, 124-127 cm. 17. Bolivina sp. 21, Sample 548-16-5, 124-127 cm. 18. Bolivina sp. 23, Sample 548A-11-3, 45-48 cm. 19. Bolivina sp. 24, Sample 548-18-4, 17-19 cm. 